\title{
THE EFFECTS OF DNA EVIDENCE ON PROPERTY OFFENCES IN COURT
}

\author{
Michael Briody 1
}

Contact:

Michael Briody

Michael.Briody@student.griffith.edu.au

Ph (07) 3878 4720, 0439077648 (mobile), fax (07) 33644636

Postal address: 13 Eccleston St.,

Fig Tree Pocket, Qld., 4069

\footnotetext{
${ }^{1} \mathrm{PhD}$ School of Criminology and Criminal Justice, Griffith University:

$<$ Michael.Briody@student.griffith.edu.au>. The author acknowledges the assistance of the Queensland Police Service (QPS) and Queensland Health Scientific Services (QHSS). Opinions expressed are not those of the QPS or of QHSS, while responsibility for any errors of omission or commission rests solely with the author.
} 


\title{
THE EFFECTS OF DNA EVIDENCE ON PROPERTY OFFENCES IN COURT
}

\author{
Michael Briody ${ }^{2}$
}

\begin{abstract}
This article evaluates the effectiveness of DNA evidence in court for property crime cases, particularly burglaries and car thefts, based on Queensland data. Published statistics and victim surveys are used to outline levels of property crime in the State and the impact of such offences on members of the community. The effects of DNA were assessed within a context of other evidentiary and extra-legal factors that may also have a bearing on case outcomes. A sample of 200 cases, referred by police for prosecution and completed past the appeal stage was examined. Half of these cases utilised DNA evidence, while the other half, as a control group, did not. DNA evidence emerged as a predictor of whether or not cases would reach court and it showed a highly significant association with guilty pleas and with the imposition of custodial penalties. The implications for criminal justice costs that arise from the association with increased guilty pleas are discussed.
\end{abstract}

\section{Introduction and background}

DNA databases, both in Australia and the UK, were introduced and then extended, on the basis that they would target property offences, among which were domestic burglaries and car thefts (Vanstone 1998: 13-17; Blakey 2000: xii, 13). This application of DNA databases was, in turn, used to justify legislation that provided for extensive DNA sampling of suspects to help apprehend those responsible for such offences (Green 2000: 10). Despite this, while a review of the literature revealed papers that provided a more general overview of DNA use in the Australian criminal justice system (Gans and Urbas 2002, for example), no Australian criminological

\footnotetext{
${ }^{2} \mathrm{PhD}$ School of Criminology and Criminal Justice, Griffith University:

$<$ Michael.Briody@student.griffith.edu.au>. The author acknowledges the assistance of the Queensland Police Service (QPS) and Queensland Health Scientific Services (QHSS). Opinions expressed are not those of the QPS or of QHSS, while responsibility for any errors of omission or commission rests solely with the author.
} 
studies were found that evaluated the effects in court of DNA evidence on such offences.

Property crimes, burglaries of people's homes in particular, and theft of motor vehicles, are well known to impair quality of life and to impact on community morale. Crimes against property in general though, include a broader range of offence types, which have been categorised for reporting purposes. The Queensland Police Service (QPS) has provided a breakdown by percentages for each crime type that it defined as a property offence. For 2003-04, these were: Other Theft (40\%), followed by Unlawful Entry offences (23\%), Other Property Damage (17\%), Fraud (11\%), Unlawful Use of Motor Vehicles (5\%), Handling Stolen Goods (3\%) and Arson (1\%). The reported numbers for most property offence types in the State have been declining since around 2000, with an overall decrease for 2003-04 of $8 \%$ on the previous year when allowing for population growth (QPS, 2004: 12, 38). This decline reflects the position in most other Australian States (Australian Institute of Criminology, 2003: 39-40). This is no reason for complacency, however, as crime rates in Australia are still very high. An International Crime Victim Survey has shown that Australia victimisation rates the worst of 17 industrialised countries, with up to $30 \%$ of the population as crime victims each year, most of these being property offences (van Kesteren et al 2000).

In the year ending March 2000, a crime victim survey estimated 5.8\% $(77,588)$ of Queensland households were victims of break and enter offences. Those more likely to be victims of such offences, or attempts at such, tended to live in close proximity to public places like hotels, parks, schools, shops and public transport. Nearly fourfifths $(78.9 \%)$ of such incidents resulted in property being stolen (Office of Economic and Statistical Research 2001: 2-3).

The most recent Crime and Safety Survey suggested that about $44 \%$ of people in Queensland perceived housebreaking or burglaries to be a problem in their neighbourhoods, while about one in four considered car thefts to be a problem. (Australian Bureau of Statistics 2003). However, only 76.6\% of break and enter victims reported the incident to police. It was found for the same year, that 
households with incomes over $\$ 104,000$ had the greatest likelihood of being victimised, and that $1.4 \%$ of households had experienced the theft of a motor vehicle. For motor vehicle thefts, 98.1\% were reported to police (Office of Economic and Statistical Research 2001: 2-3). In 2000, rates of recorded crime per 100,000 people for property crimes in Queensland were slightly below the national average, while little difference was found between Queensland crime victimisation rates and those of Australia as a whole (Criminal Justice Commission 2001: 2).

One measure of the impact of DNA on property crimes was taken by comparing the numbers of reported such offences in Queensland to numbers of cases referred to the laboratory. At the time of the research, the jurisdiction of Queensland had one forensic biology laboratory, and only in rare instances, such as for mitochondrial DNA (mtDNA) testing, were samples sent elsewhere for testing (Doneman, 2001: 1). Although the Australian Federal Police operated within Queensland, it was the State Police Service that almost exclusively concentrated on property crime, unless the property targeted belonged to the Commonwealth. This congruency facilitated comparisons.

In 2002-03, police referred samples from 4,894 property crimes to the State's forensic laboratory for analysis (QHSS 2003). In the same year, the Annual Statistical Review of Queensland Police Service reported 278,995 property offences in the State, of which police cleared 27\% (QPS 2003: 4), while the Police Minister reported a total of 1,100 DNA identifications for all offence types including crimes against the person (Queensland State Budget 2003-04: 16). The fact that less than two percent of property crimes were referred to the laboratory, would suggest that forensic DNA could, at best, have only a minimal impact on solving property offences in the State to that point in time. The impact would be further reduced by the laboratory backlog of crime scene exhibits. Some measure of the potential for DNA may be drawn from the experience in the UK, which has operated a national DNA database since 1995. In England and Wales to 31 March 2001, for burglary, and for offences of theft of and from vehicles, the police services achieved a clear-up rate of 9.9\%. They attributed one third of these clear-ups $(3.3 \%)$ to forensic science, with DNA responsible for 
around $1.1 \%$ and fingerprints for 2.2\% (Burrows and Tarling 2004: 221; see also Briody and Prenzler 2005).

\section{Hypotheses to test}

As mentioned, no previous comparative Australian studies were found that examined the effects of DNA on property offence cases in court, although some studies examined guilty plea rates. In the United Kingdom (UK), Martin Gaule (1999: 1-6), then Scientific Support Manager for the Sussex Police, compared outcomes from a pilot group of 308 crime scene DNA samples processed through the forensic laboratory with a turn-around time of 28 days, to a control group of 336 DNA samples with no turn-around time constraints. The rate of guilty pleas for cases in the pilot group, mostly property crime offences, was considered high at $80 \%$, although Gaule made no comparison with the rate of guilty pleas in the control group, or with any group of similar non-DNA cases. A New Zealand study that sampled seventeen cases involving 50 burglary charges, five rape offences and one homicide, all of which relied on DNA evidence, found that in all cases but one the defendant pleaded guilty (Walsh et al 2002: 213).

Hypotheses for testing were based on the proposition that incriminating DNA evidence based on samples from crime scenes would increase the effectiveness of prosecutions. The hypotheses were:

1. That a higher proportion of property offence cases would reach court where DNA evidence was available to prosecutors;

2. That more guilty pleas would result where suspects were confronted with DNA evidence associating them with crime scenes or with exhibits like stolen property;

3. That a significant relationship exists between DNA evidence implicating the accused and the likelihood of a conviction;

4. That incriminating DNA evidence is associated with more custodial penalties;

5. That custodial penalties imposed are longer for cases with DNA evidence. 
The hypotheses relating to the sentencing phase were included as a result of studies on the effects of trace forensic evidence in the United States prior to the use of forensic DNA testing, when serological, fibre, hair, shoe mark and fingerprint comparison were used. While these studies researched the effects on offences against the person as well as on property crimes, they reported, "forensic science reports and testimony have their greatest impact at the time of sentencing, when convicted defendants are more likely to go to prison and for longer periods of time where scientific evidence is presented" (Peterson et al 1987: 1730). Sentencing in Australia, however, is conducted in a different legal context to that in the US, where juries play a role in some sentencing decisions. In Australia they play no such part, but nevertheless it was decided investigate whether DNA evidence demonstrated any relationship to sentencing decisions. The hypotheses were then tested using a control-comparison method.

\section{Method}

The sample selected for analysis consisted of 200 criminal cases, half of which used DNA evidence. The remaining 100 did not include forensic DNA and provided a control group. After appropriate ethical permissions were obtained, the cases with DNA were chosen from Queensland Health Scientific Service's (QHSS) forensic laboratory case files. The trace biological evidence most commonly located at crime scenes such as burglaries, and from recovered stolen motor vehicles was taken from cigarette butts, from cans and bottles used to consume drinks, from clothing like baseball caps, from blood when perpetrators had cut themselves (for example, on broken window glass) or from syringes left at the scene. Occasionally, chewing gum or partially eaten foods were taken for testing (Wilson-Wilde 2001: 4; see also Sears et al 2002). The range of dates selected for the cases was from 25 March 1994 through to 13 January 2001.

The majority of cases sampled occurred during 2000, because the number of property offences at which DNA was collected as evidence was relatively limited in the earlier years, with priority for testing being allocated to more serious offences against the person. In 2000 also, legislation was enacted in all Australian States and Territories 
to facilitate the use of DNA profiling, by, for example, allowing the testing buccal swabs and hair roots as an alternative to blood samples. This legislation also enabled the establishment of a national criminal DNA database. In Queensland the legislation was incorporated in the Police Powers and Responsibilities Act 2000 (Green 2000; Gans 2002). In the later years, advances in technology were also allowing profiles to be derived from increasingly small and degraded samples (Raymond et al. 2004: 668687).

The selection criteria for the cases with DNA were:

- that the cases be completed so that they could be tracked to finality in the justice process, that is, past the appeal stage in the courts. This means that cases selected through this criterion either were not appealed within the prescribed period, or if they were appealed, the appeal result was regarded as the final outcome;

- that a forensic laboratory scientist had produced a sworn court statement in which the defendant was associated through DNA profiling with either the complainant or the crime scene;

- that police and court records could be located;

As in most Western countries, juveniles were found responsible for committing many of the property offences and therefore constituted a significant proportion of offenders. In Queensland, such persons are subject to provisions of the Juvenile Justice Act 1992 (Qld). Under the Act, police officers, usually members of the Juvenile Aid Bureau, may administer a formal caution provided certain conditions, such as making an admission to the offence, are met. For the purposes of statistical data analysis, such instances were regarded for this study as pleas of guilty and counted as convictions.

The control group of 100 property offence cases was chosen from the computerised records of the Queensland Police Service, again after ethics approvals were obtained. These cases were taken from within the same time bracket and jurisdiction in order to place them in a contemporaneous social and legal context and to meet the same selection criteria, in point form above, except for the second. This control group was 
not a random sample, but was selected to mirror the DNA group as far as possible, in order to minimise biases when conducting comparisons. Data on court outcomes were accessed throughout 2002 via microfilm held at the QPS Police Information Centre, thereby allowing a two-year interval for processing of cases by the courts and for appeals. The sample population of 200 cases was of sufficient size in relation to the number of independent variables to allow significant relationships to be calculated statistically through to the plea stage (Tabachnick and Fidell 2001: 521-2). However, not all variables were found available for every case in the records consulted.

A necessary element of parity between both groups in the sample was a rating for the seriousness of the offences when cases reached their final court hearing. This measure was calculated in order to pre-empt the possibility that only more serious incidents were referred for DNA testing. The thirteen level scale of offence seriousness, where thirteen was the most serious in the hierarchy of offences (robbery under arms) and one was the lowest (unlawful trespass or graffiti) was constructed. This was based on the Australian Bureau of Statistics "order of seriousness of offence types" as set out in Appendix 6 of the Queensland Government Statistician's publication Crime and Justice Statistics, Queensland, 1997 (1998: 58, 59).

1. Unlawful trespass; graffiti.

2. Vehicles: enter with intent or steal from.

3. Motor vehicle: steal, unlawfully use, possess.

4. Robbery, unarmed.

5. Stealing from dwelling houses.

6. Enter with intent, other premises, with breaking.

7. Enter with intent, shop, with breaking.

8. Burglary with breaking.

9. Driving causing Grievous bodily harm.

10. Robbery, unarmed, in company.

11. Burglary with violence or threats.

12. Burglary with violence or threats, with breaking.

13. Robbery under arms. 
The mean value of "seriousness", based on the charges finally faced in the District Courts, was calculated on this thirteen-tiered scale. For DNA cases this value was 6.54 and for non-DNA cases was 6.67. These values were sufficiently close to achieve valid results, with the non-DNA cases rating a slightly higher degree of seriousness. This confirmed that the cases referred for profiling were no more serious than the non-DNA cases, thereby avoiding a bias towards the DNA cases in the comparison. The distribution of the offences was such that the burglary type offences, numbers 5 to 8 on the scale, accounted for $73.5 \%$ of cases overall, 73 being DNA cases and 74 non-DNA. The vehicle offences, numbered 3 on the scale, formed a further five percent overall. Hence, common property crime formed close to $80 \%$ of the sample.

The sample of offences from the forensic laboratory did not correspond precisely to the police definition of property offences. No fraud or arson cases, for example, were included among the cases sampled, suggesting that investigations based on trace DNA evidence may be unsuited for such offence types. On the other hand, the laboratory included "driving causing grievous bodily harm" among property offences, as is included in Table 1.

A listing of descriptors of the independent or predictor variables for the cases sampled is set out in Table 1, along with their means and standard deviations where meaningful. The independent variables are divided into three general categories: offence type variables, evidence variables and defendant variables. As the offences were primarily directed towards property, no complainant variables were included, as victims comprised not only persons, but also businesses and government departments. Social data, such as age, race and gender of defendants were obtained from QPS sources and recorded, as these may also have had a bearing on case outcomes (White and Perrone 1997: 91-101).

A category of "immediate arrest", defined as arrest occurring within 24 hours, was used to include offenders "caught in the act" by, for example, rapid response policing. Apart from where indicated on the Table, most predictor variables were dichotomous, with the value of one (1) reflecting inclusion in the category. Dummy variables were 
used for non-binary values like defendant race and police interview statement. Where independent variables were in scale form, such as seriousness of offence or offender age, they were collapsed into binary form. For seriousness of offence, the median was used as the divide, while offender ages were separated into those aged 16 years or less, with the remainder as adults. This division reflected the provisions of the Juvenile Justice Act 1992 (Qld) at the time the cases occurred, where a person under 17 years of age was defined as a child. As not all data were available for every case, a column is included to indicate the number of cases for each variable where data were available. 
Table 1: Independent Variables Examined: 200 Property Offence Cases

\begin{tabular}{|c|c|c|c|c|c|}
\hline Variable Name & $\begin{array}{l}\text { No of valid } \\
\text { Cases } \\
\end{array}$ & Mean & SD & Min. & Max \\
\hline \multicolumn{6}{|l|}{ Offence Type Variables } \\
\hline $\begin{array}{l}\text { Most serious offence charged } \\
13=\text { Robbery under arms } \\
12=\text { Burglary with violence and breaking } \\
11=\text { Burglary with violence or threats } \\
10=\text { Robbery unarmed in company } \\
9=\text { Driving causing grievous bodily harm } \\
8=\text { Burglary with breaking } \\
7=\text { Break and enter shop with intent } \\
6=\text { Break and enter other with intent } \\
5=\text { Stealing from dwelling houses } \\
4=\text { Robbery, unarmed } \\
3=\text { Unlawfully use, steal motor vehicle } \\
2=\text { Enter or steal from vehicles } \\
1=\text { Graffiti, drink driving }\end{array}$ & $\begin{array}{l}200 \\
4(2 \%)^{*} \\
6(3 \%) \\
19(9 \%) \\
2(1 \%) \\
21(11 \%) \\
47(24 \%) \\
27(14 \%) \\
52(26 \%) \\
3(2 \%) \\
4(2 \%) \\
5(3 \%) \\
4(2 \%) \\
6(3 \%)\end{array}$ & 6.61 & 2.47 & 0 & 13 \\
\hline \multicolumn{6}{|l|}{ Evidence Variables } \\
\hline Fingerprints $(1=$ present $)$ & 199 & 0.15 & 0.35 & 0 & 1 \\
\hline DNA court statement $(1=$ present $)$ & 200 & 0.50 & 0.50 & 0 & 1 \\
\hline $\begin{array}{l}\text { Independent witness(es) to offence } \\
(1=\text { present })\end{array}$ & 197 & 0.35 & 0.48 & 0 & 1 \\
\hline Photographic or video evidence $(1=$ present $)$ & 198 & 0.61 & 0.49 & 0 & 1 \\
\hline Tangible evidence $(1=$ present $)$ & 198 & 0.38 & 0.49 & 0 & 1 \\
\hline Immediate arrest $(1=$ arrest within 24 hours $)$ & 195 & 0.23 & 0.42 & 0 & 1 \\
\hline \multicolumn{6}{|l|}{ Defendant Variables } \\
\hline Defendant age at time of offence (years) & 198 & 22 & 7.6 & 12 & 60 \\
\hline $\begin{array}{l}\text { Defendant employed at time of arrest } \\
(1=\text { employed })\end{array}$ & 194 & 0.15 & 0.36 & 0 & 1 \\
\hline $\begin{array}{l}\text { Defendant race } \\
0=\text { Caucasian } \\
1=\text { Indigenous } \\
2=\text { other }\end{array}$ & $\begin{array}{l}195 \\
132(68 \%) \\
53(27 \%) \\
10(5 \%) \\
\end{array}$ & & & & \\
\hline Defendant is male $(0=$ female; $1=$ male $)$ & 199 & 0.93 & 0.25 & 0 & 1 \\
\hline $\begin{array}{l}\text { Defendant statement: } \\
0=\text { denies committing offence } \\
1=\text { makes no statement } / \text { refuses interview } \\
2=\text { makes some admissions } \\
3=\text { confesses to offence }\end{array}$ & $\begin{array}{l}176 \\
13(7 \%) \\
86(49 \%) \\
10(6 \%) \\
67(38 \%) \\
\end{array}$ & & & & \\
\hline $\begin{array}{l}\text { Defendant has prior convictions for similar } \\
(1=\text { has priors })\end{array}$ & 193 & 0.93 & 0.25 & 0 & 1 \\
\hline
\end{tabular}

* Due to rounding of numbers, percentages may not add up to 100.

Note: Measures of central tendency and dispersion are listed only for interval level measures. Means also are shown for all binary measures to indicate the proportion of cases in those categories coded "1". 


\section{Effects of DNA evidence on the court process: Data analysis}

To gauge the effects, if any, of DNA evidence on the various decision-making stages in the courts, a multivariate technique was employed. Dichotomous dependant variables were defined as:

- Whether the case reached court (coded as 1) or did not (coded as 0 );

- Whether the accused pleaded guilty (coded as 1 ) or did not (coded as 0 );

- Whether there was a conviction (coded as 1$)$ or not (coded as 0$)$;

- Whether a custodial penalty was imposed (coded as 1$)$ or not (coded as 0$)$.

The only dependent scale variable was length of custodial penalty, and only values other than zero were included in the analysis, so that for example, sentences for offenders detained until the rising of the court were excluded. (Sentencing until the rising of the court is a practice not widely used outside Queensland, and is a nominal custodial sentence only). A series of bivariate analyses was conducted to explore the relationship between each predictor variable and the dependent variables. These were then followed by logistic regression analyses to provide likelihood ratios and predictor equations.

\section{Results of statistical analyses}

Table 2 shows the bivariate Pearson correlation coefficients examined to determine the significance of these relationships. The three columns in the Table provide the coefficients for the disposition; that is, whether or not cases reached court, and for court outcomes. Although data on disposition were found for all 200 cases, whether or not a guilty plea was entered could be ascertained from the criminal histories consulted only in 170 cases. However, data on whether convictions resulted were found in 196 cases. The 26 cases for which there were convictions but the plea type was unknown may have been summary trials, the charge or charges may have been tried in a higher court or before a jury, some may have been guilty pleas, or the matters may have been dealt with ex officio. (Ex-officio is a process available under section 561 of Queensland's Criminal Code. It is used particularly when defendants 
are subject to numerous charges that they prefer cleared up and dealt with, and where they wish to enter a plea of guilty and proceed directly to the District or Supreme Court. Recidivists, who can be subject to many charges, have been found to commit a large proportion of property offences (Salmelainen 1995). One penalty is normally imposed in relation to an ex-officio guilty plea. Through the Office of the Director of Public Prosecutions (DPP), the Crown can present an ex-officio indictment in the higher court, which bypasses any committal proceeding. A sentencing discount is given for those who plead ex-officio as this saves the court and police time, because generally, a full brief of evidence does not need to be presented). 
The scale variable for offence type was also converted to binary form, with cases at levels 1 to 6 on the scale designated zero, and levels seven to thirteen rated at one. The " $p$ " values were set at the conventional significance levels of 0.05 and 0.01 .

Table 2: $\quad$ Bivariate Pearson Correlation Coefficients between Dependent and Independent Variables - Court Processing of Property Offence Case

\begin{tabular}{|c|c|c|c|}
\hline Independent Variables & Disposition & \multicolumn{2}{|c|}{ Court Outcome } \\
\hline Description & $\begin{array}{l}\text { Reached Court } \\
\qquad(\mathrm{N}=\mathbf{2 0 0})\end{array}$ & $\begin{array}{c}\text { Guilty Plea } \\
(\mathbf{N}=170)\end{array}$ & $\begin{array}{c}\text { Convictions } \\
(\mathrm{N}=196)\end{array}$ \\
\hline Seriousness of offence & -0.012 & 0.023 & 0.020 \\
\hline Fingerprint evidence & -0.073 & $-0.168^{*}$ & -0.077 \\
\hline DNA evidence & $0.204 * *$ & $0.193 * *$ & $0.182 * *$ \\
\hline Independent witness(es) & 0.002 & -0.022 & -0.030 \\
\hline Photographic evidence & $0.131^{*}$ & 0.102 & 0.110 \\
\hline Tangible evidence & 0.023 & 0.056 & 0.025 \\
\hline Immediate arrest & $0.118^{*}$ & $0.142 *$ & $0.123^{*}$ \\
\hline Defendant age at time of arrest & 0.050 & -0.106 & -0.083 \\
\hline Defendant employed & 0.006 & $-0.134 *$ & -0.043 \\
\hline Defendant Caucasian race & 0.008 & 0.072 & 0.004 \\
\hline Defendant Indigenous race & -0.011 & -0.072 & -0.008 \\
\hline Defendant other race & 0.005 & -0.007 & 0.007 \\
\hline Defendant was male & -0.096 & -0.098 & -0.098 \\
\hline Defendant confessed & -0.002 & 0.053 & 0.034 \\
\hline Defendant made admissions & 0.010 & 0.009 & 0.010 \\
\hline Defendant denied offence & 0.024 & -0.086 & -0.048 \\
\hline Defendant made no statement & -0.008 & -0.006 & -0.006 \\
\hline Prior record similar & -0.026 & 0.051 & 0.051 \\
\hline Number of charges & 0.004 & 0037 & 0.043 \\
\hline Guilty plea & N/A & N/A & $0.941 * *$ \\
\hline
\end{tabular}

$* \mathrm{p}<.05 ; * * \mathrm{p}<.01$ 
Three independent variables can be seen in the first column of Table 2, "Reached Court", to be correlated significantly with whether or not cases reached court. DNA evidence proved to have the highest significance, at below the .01 level, followed by photographic evidence and then by immediacy of arrest, defined as arrest within 24 hours. In the second column, "Guilty Plea", DNA evidence also demonstrated a highly significant relationship with guilty pleas by defendants, followed by immediacy of arrest. Two other variables showed negative relationships with pleas of guilt: fingerprint evidence and the defendant being employed. In the third column, "Guilty Result", a guilty plea, as would be expected, was the variable most significantly related. This was followed by DNA evidence, significant below the .01 level, then by immediacy of arrest.

The overall results from the 200 cases sampled, were that in 23 cases charges were withdrawn, that is, prosecutors had no evidence to offer (NETO) in the Magistrate's Courts or cases were finalised through a nolle prosequi in the higher court, resulting in 177 cases reaching court. In 30 of the 200 cases, records accessed did not indicate whether finalisation was through a plea or trial, but of the remaining 170 known, 151 were finalised with guilty pleas while 19 defendants pleaded not guilty. From the 196 of the 200 cases whose results were found in the records, there were 173 convictions (guilty pleas plus court verdicts) and 23 non-convictions (court verdicts, jury acquittal plus NETO/nolle prosequis). From the 173 convictions, a custodial penalty was imposed in 83 instances; although in only 78 cases did the offender spend time in prison.

From the DNA, 95 cases reached the courts, 78 were guilty pleas, and the remaining seventeen cases were adjudicated. From the non-DNA group, 82 reached court, 73 were guilty pleas and the remaining nine were decided before the courts. Where guilty pleas were entered, Magistrates were provided with a Police Court Brief (Form QP9) that summarised the case. However, this brief would not necessarily mention the DNA evidence, therefore it was not possible to attribute conclusively to DNA any effects on sentencing decisions. For guilty plea cases that went to the District Courts, including those that went ex-officio, while the DPP provided a summary of the case to the judge, it did not present the evidence before the court in a trial. Hence DNA could not be 
considered an independent variable for the purposes of the analysis, as no direct nexus existed between the DNA evidence and sentencing decisions.

Of the nine cases that went before the courts because of "Not Guilty" pleas, only one from the DNA group resulted in a guilty finding followed by a custodial penalty. No parallel cases at all in the control group went before the courts with the outcomes of a guilty finding and a custodial penalty. That there was only one sentencing decision in 100 cases where it was known for certain that forensic DNA could be a potential influence meant that it was not possible to determine statistically any influence DNA may have had on sentencing decisions.

To conclusively relate DNA evidence to sentencing decisions, a sample with a viable number of cases would need to be selected at the point of sentencing. Correlations were still conducted as part of this research to test for any relationship between the presence of DNA evidence and the sentencing disposition. The value of the Pearson bivariate positive correlation between DNA and the imposition of a custodial penalty was highly significant $(\mathrm{p}<.01)$ at $0.236(\mathrm{n}=173)$, but there was a negative, non-significant correlation with the length of the sentence, the value being $-0.152(n=78)$. While the former value implies a link between DNA evidence and sentencing, dedicated research on the sentencing stage would be required to explain any such link theoretically.

Despite this lack of explanation about the relevance of DNA to sentencing decisions, a multiple regression analysis of the 78 guilty plea cases with custodial penalties was conducted. This aimed to relate the penalty length to defendant and offence variables, but it did not include evidentiary independent variables such as DNA, as its relevance to sentencing decisions was uncertain. This analysis, not shown in the Tables, found that the seriousness of the offence was the sole predictive factor in determining the length of imprisonment.

Following the bivariate analyses in Table 2, multivariate analyses were conducted. Table 3 shows the results of the logistic regression analyses for the three stages of the case 
reaching court, of guilty pleas and of guilty outcomes. These analyses related the independent predictor variables to the outcome stages. Logistic regression models were created using SPSS version 9.0 for Windows software. Variables found to have a significant relationship in the bivariate analyses were entered to create a full model, and then those that were not predictive were removed. In the reduced model, only the independent variables that were statistically significant below the 0.10 level were retained (Poulos 1993: 26). By being incorporated simultaneously in the model, the variables controlled for each other's effects. 
Table 3: $\quad$ Significant Predictor Variables from Logistic Regression Analysis: Property Offences.

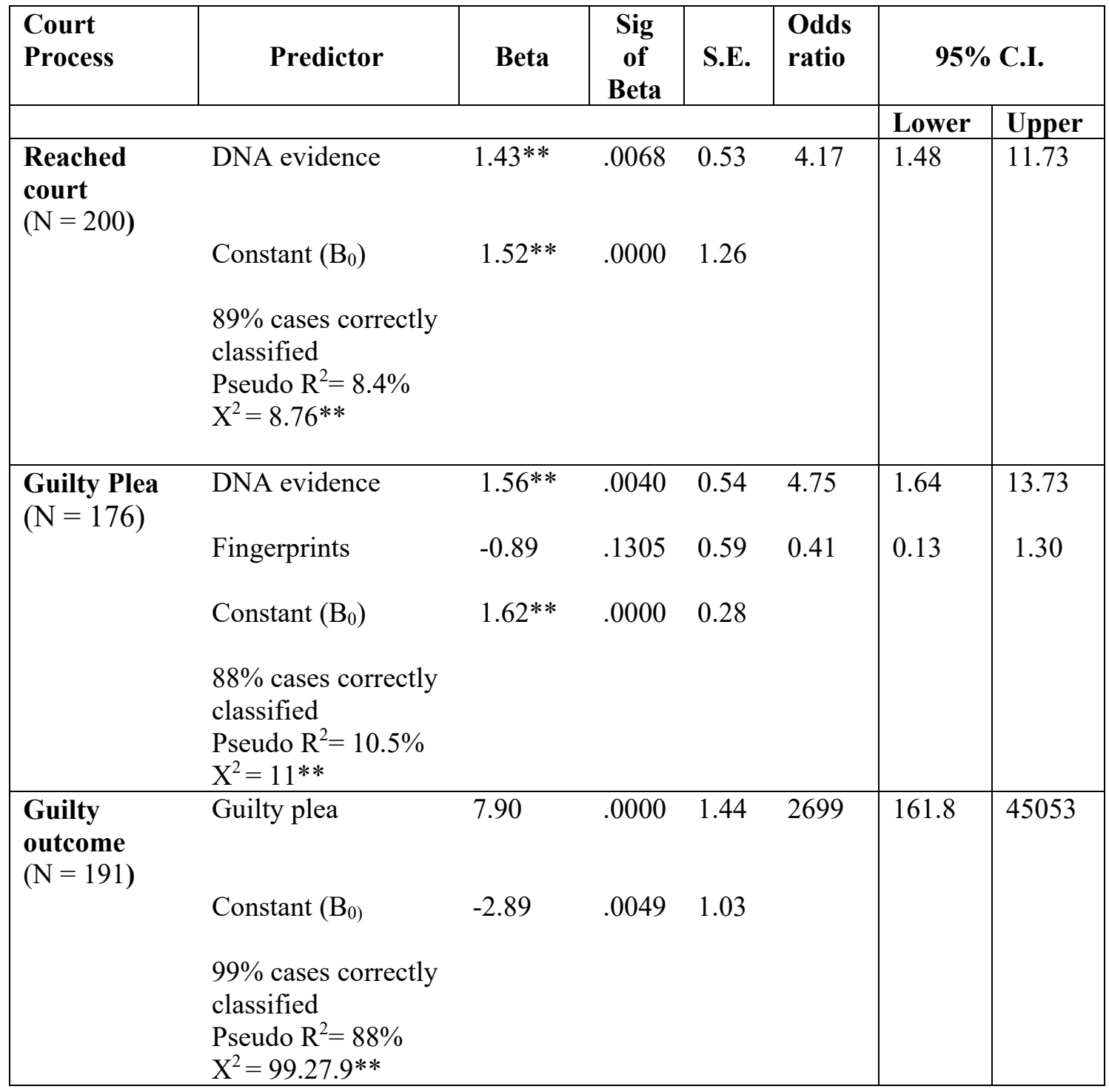

$\mathrm{p}^{*}<.05 ; * * \mathrm{p}<.01$

In Table 3, the "Predictor" column displays the independent variables that most strongly influenced the court process listed in the left column. The "Beta" column shows the logistic regression coefficient, "S.E." is the standard error, while the "Odds ratio" is the exponentiate of the Beta value. The "Odds ratio" indicates the likelihood of a particular outcome where a designated variable is present in a case. For example, in cases where 
incriminating DNA evidence was available were more likely to reach court, the odds were more than four times (4.17) times higher for DNA cases than for non-DNA ones. The lower and upper 95\% confidence intervals are reported for the odds ratio results.

\section{Predicting court results}

Table 4 gives examples to illustrate the effects of DNA evidence as a statistical predictor of the conditional probability of cases reaching court and of guilty pleas. To calculate the conditional probability for a dichotomous outcome when individual case characteristics are known, the formula used is:

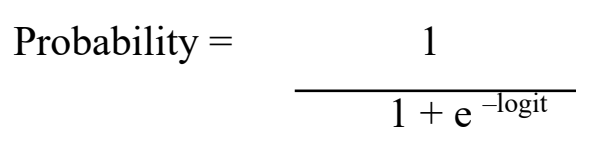

where the logit $=B_{0}+B_{1} X_{1}+B_{2} X_{2}+B_{3} X_{3} \ldots+B_{\mathrm{k}} X_{\mathrm{k}}$.

$B$ is the Beta value from Table 3 with $\mathrm{B}_{0}$ the constant. Case examples demonstrating differences forensic DNA can make to case outcomes are shown in Table 4.

The addition of DNA evidence in the prosecution of property offences did not act to change the predicted outcome at any stage in the court process. For the first phase, whether cases reached court, Table 4 shows a probability without DNA as 0.82 , while with DNA the probability increased to 0.95 . This was largely because prosecutors "offered no evidence" or entered a nolle prosequi for few property offence cases, whether or not DNA evidence was used. That is, most cases either reached court or police cautions were administered to child offenders.

As noted above, Table 3 indicates that where DNA evidence was available, cases were more likely to reach court. Similarly with the analysis of the effects on pleas of guilty, Table 3 indicated an increased probability of a guilty plea where incriminating DNA evidence was presented. For property offence cases generally, as illustrated by Cases 2 
and 3 in Table 4, defendants were likely to enter a guilty plea whether or not DNA was available.

Table 4: Conditional Probabilities of court outcomes for various case characteristics.

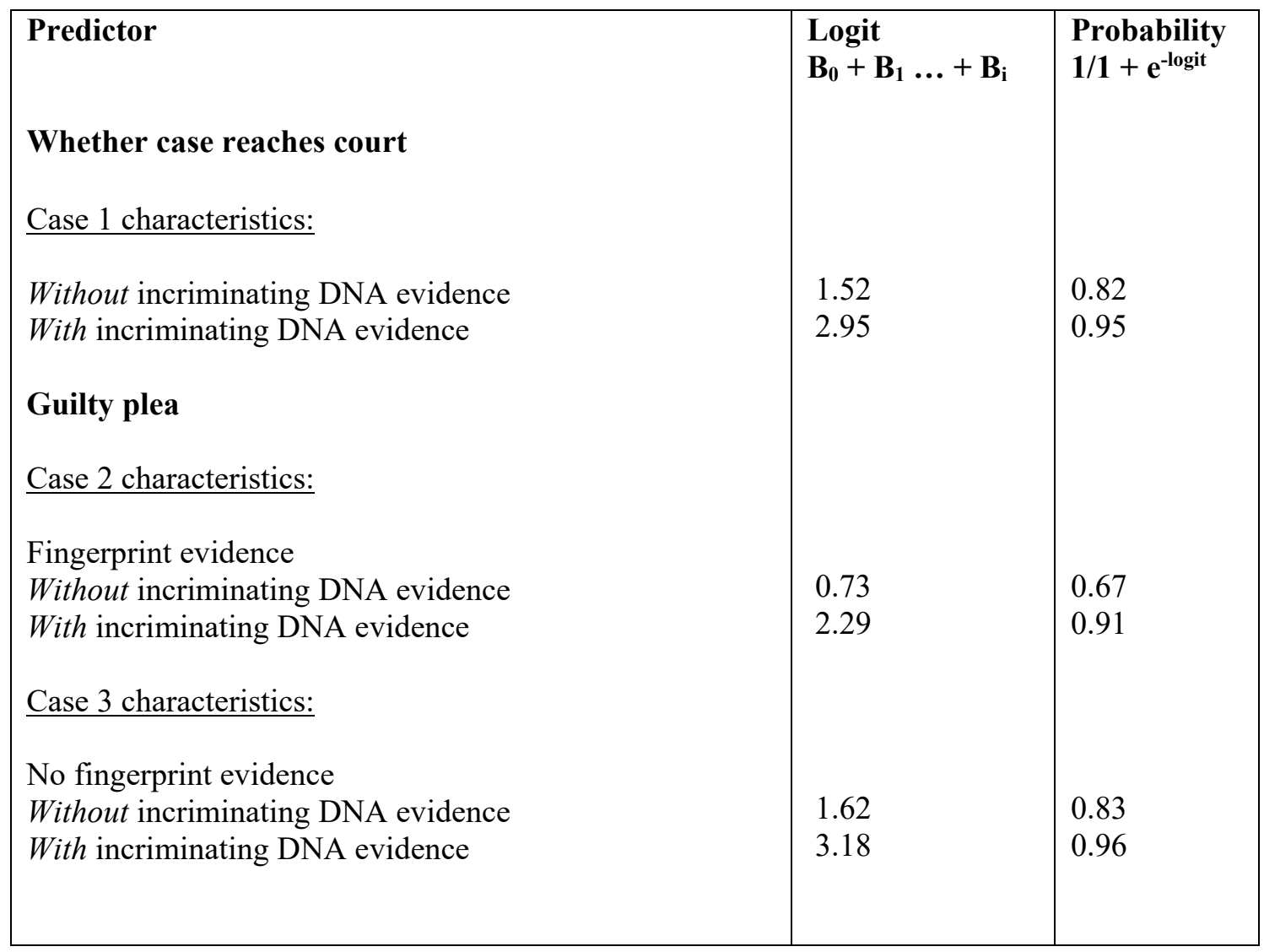

\section{Analysis and discussion: Findings in relation to hypotheses}

\section{Effects on cases reaching court}

Of the 200 cases sampled, 177 or $88.5 \%$ arrived in court without a nolle prosequi being entered by the DPP or having no evidence presented in the Magistrates' Courts. DNA evidence emerged as the sole predictor that cases would be prosecuted. This finding suggests that cases were strengthened by the presence of DNA evidence, which encouraged prosecutors to take cases to court. The addition of DNA evidence to a case 
increased the conditional probability of it reaching court from 0.82 to 0.95 . However, most property offence cases sampled were predicted to reach court even without DNA evidence being available.

\section{Effects on guilty pleas}

The relationship of DNA evidence to guilty pleas is of particular interest from a cost perspective, as savings of time to the courts may result if defendants opt to plead guilty and a subsequent hearing or trial becomes unnecessary. DNA evidence did emerge for property offences as having a highly significant relationship with decisions by defendants to plead guilty (Tables 2 and 3). This contrasts with findings for more serious offences against the person, such as sexual offences, homicides and serious assaults, where incriminating DNA evidence, when used, showed no effects on inducing guilty pleas (Briody 2002: 174-5; 2004a: 246-7; 2004b: 153).

Of 88 cases without DNA that reached court in the sample, 73 (82\%) resulted in guilty pleas. This compared to 82 cases with DNA arriving in court, of which 78 (95\%) were pleas of guilty. In 30 of the 200 cases, the records consulted did not indicate whether or not a guilty plea was entered. Counting juvenile cautions as guilty pleas in the analysis did not bias this finding. Although cautions administered to juveniles were counted as pleas of guilty for statistical purposes, no such cautions were included among the 100 cases in the DNA group. Only eight cautions, all in the control group, were among those sampled. As a condition of the formal caution, juveniles must admit to their guilt, so that confirmatory DNA tests were not requested from the laboratory in such cases. No juvenile offenders were included in the DNA group as a result of "cold matches".

Claims have been made that DNA evidence has caused more guilty pleas. The Federal Government's CrimTrac agency, which coordinates the Australian Commonwealth, State and Territory DNA databases explained, "When confronted with DNA evidence, guilty suspects may be more likely to confess and plead guilty, saving police time and reducing court costs." (CrimTrac 2004). CrimTrac's national DNA business case, in turn, relies on cost savings based on increases in guilty pleas attributed to DNA usage in order to be 
financially viable. However, the business case does not cite any studies to support this claim, quoting instead "international experience" (Nearhos and Bowman 1999: 68-69). Individual States, which in turn modelled their own business cases on the national one, are likely to have adopted this same assumption.

In relation to the association of forensic DNA with guilty pleas, Dr Alaster Smith, of the UK Home Office Policing and Crime Reducing Unit advised:

A study carried out in the UK on volume property crime suggested that offenders were more likely to plead guilty when faced with forensic evidence, including both fingerprints and DNA (Smith 2003).

The fact that DNA evidence did emerge as a predictor of guilty pleas for property offences suggests that projected savings might be factored into cost-benefit evaluations. However, any perceived savings are likely to be restricted by the very limited extent that DNA evidence featured in prosecutions for property offences overall. This suggests only very marginal savings are likely through such guilty pleas. A large majority of property offence cases ended in guilty pleas, or with formal cautions, irrespective of the presence of DNA. While the timing of any guilty pleas, and changes of plea during trial are relevant to costs, the police records accessed for this research provided only the final plea type of the defendant, and not the timing of that plea. Cases were predominantly adjudicated in the Magistrates and Children's courts, where costs are considerably less than those in the District or Supreme Courts. Nearly all property cases with DNA evidence that did reach the superior courts were prosecuted in conjunction with larger numbers of non-DNA cases. Many went ex-officio with a guilty plea, while only one case was sampled that was decided by a jury.

No estimates were available on Magistrates' Court costs in Queensland with or without guilty pleas (Ward 2004), but figures from the UK indicated that the average cost of a guilty plea in a Magistrate's Court was around $£ 450$, compared with $£ 1,700$ for hearing a case before a Magistrate following a not guilty plea (Harries 1999). In 2002-03, the 
proportion of property offences where DNA evidence was used during investigations in Queensland was less than two percent, with a further attrition of case numbers to well below one percent by the time these arrived at the courts. This usage level is consistent with studies in the UK and in New Zealand that found three to five percent of burglaries yield trace DNA evidence (Blakey 2000: 18-21; Walsh et al 2002: 212). Any projected savings from guilty pleas, therefore, would apply only to the thirteen percent margin or thereabouts, on the less than one percent of cases using DNA.

On the other hand, as in Victoria, any potential savings to the courts are likely to be outweighed by costs associated with delays in processing samples from property offences backlogged in laboratories (Victorian Parliament Law Reform Committee 2004: 473). Costs of staff and equipment to clear the backlogs will no doubt reduce any possible savings. This position was illustrated early in 2004, when the Queensland government pledged \$11 million over the following three years towards removing the backlog (Australian Labor Party 2004).

\section{Effects on jury verdicts}

Of the 200 property offence cases sampled, only one was known to have gone before a jury in the District Court. Most property offence cases, being of a less serious nature than crimes against the person, were decided in the Magistrates' Courts. Other cases proceeded ex-officio directly to the higher courts after police prosecutors had No Evidence to Offer (NETO) in the Magistrates' Courts.

In the one case known to have gone before a jury, the 18-year-old defendant, whose occupation was given as a professional athlete, was charged with wilful damage. This involved a broken window at a service station in the Brisbane suburb of Hamilton. The attendant alleged that the offence occurred while three persons were assaulting him in the early hours. The complainant was unable to recall the incident clearly when interviewed by police. However, blood was swabbed from the broken window, and matched through DNA to the defendant, who denied the offence but was found guilty by a jury (Case P44; QPS CRISP; QHSS File F17046). The lack of jury cases prompted two conclusions. 
First, it was not possible to determine statistically any effects that DNA evidence might have had on jury decisions in property offence cases; and second, the fact that property offence cases decided by juries were very much the exception, indicated that the effects of DNA on juries in such cases would not constitute a significant topic area for research compared to other offence types - sexual assaults, for example. No decisions on property offence cases were found to be appealed against on the basis of DNA evidence. This compared with the one Australian case involving a rape complaint where the Queensland Court of Appeal upheld an appeal on the basis of DNA evidence (Australian Broadcasting Commission 2002; Crime and Misconduct Commission 2002; R. v. Frank Alan Button [2001] QCA 133).

\section{Effects on the imposition of custodial penalties}

As noted earlier, only one of 100 cases sampled with DNA was heard before a court and this resulted in a custodial penalty. This outcome meant that a statistical evaluation of the DNA at the sentencing stage based on the present sample would not yield meaningful results. Of 173 convictions in the 200 cases sampled, 93 custodial penalties were imposed. The high proportion of guilty pleas, as mentioned above, largely negated ascertaining any relationship between DNA evidence and sentencing decisions. Where guilty pleas were entered, the courts were not necessarily aware of any DNA evidence when pronouncing sentences.

Of the 95 DNA cases that reached court, 94 resulted in guilty outcomes, and in 60 of these cases (64\%), custodial penalties were imposed. This compared with 82 non-DNA cases reaching court, where 79 had guilty outcome. Of the 79 cases, 33 cases (42\%) resulting in defendants being given prison sentences. Of the total of 93 custodial penalties (60 DNA and 33 non-DNA), fifteen were suspended immediately, so that offenders served time in prison in only 78 of the cases.

As was noted above, where guilty pleas were entered it was not possible to ascertain whether prosecutors in the Magistrates' Courts included on their court briefs the fact that incriminating DNA was available. Research in the United States found that, even when 
available, "DNA is not used by a majority of prosecutors' offices... [and] even those prosecution offices that use DNA evidence do not use such evidence beyond the two most serious crime types [homicide and rape]" (Tracy and Morgan 2000: 658-9). A survey of Australian prosecutors may be warranted to determine the level of usage of DNA evidence, when it is available, for property offences.

\section{Effects of the severity of custodial penalty}

As noted above, $95 \%$ of cases with DNA and $88 \%$ of cases without culminated in pleas of guilty. This meant that in a large majority of cases the DNA evidence was never testified to in court and Magistrates were only aware of it if it were mentioned on the prosecutor's brief. In the District Courts for guilty pleas, the judge is not provided with the evidence during sentencing, but may be made aware of it in a summary of the case. After guilty pleas, only one case with DNA remained where the evidence was heard in court and a custodial penalty resulted. No parallel cases were available in the control group. With this outcome, no statistical analysis relating DNA to length of sentence was possible. Nevertheless, the 78 guilty plea cases with custodial penalties were analysed to relate the penalty length to defendant and offence variables. It was found from a multiple regression analysis that the seriousness of the offence was found to be the sole predictive factor in determining the length of imprisonment.

\section{CONCLUSION}

DNA evidence was found to be collected at only a small proportion of property offence investigations, the majority of these being burglaries of premises and motor vehicle thefts. A control-comparison method was used to assess the effects of DNA evidence on

property offences by statistically comparing 100 cases that used DNA evidence to 100 similar cases without, and tracking their progress though the justice process. Where prosecutors presented it, DNA demonstrated a number of effects on decisions at various stages in the court process. Cases were more likely to be brought to court by prosecutors, rather than to have no evidence offered or a nolle prosequi entered, and defendants were 
more likely to enter pleas of guilty with the courts. However, as a large majority of all property offences referred by police for prosecution arrive in court, and most of these involve pleas of guilty, the addition of DNA evidence to case configurations did not alter predicted outcomes. Cost savings, if any, through guilty pleas were likely to be minimal, due to the small proportion of cases that utilised DNA and to the fact that nearly all such cases went before Magistrates', rather than before superior, Courts. At the sentencing stage, while DNA evidence showed a highly significant positive statistical relationship with custodial penalties, it could not be determined conclusively whether this correlation implied causation. Neither was DNA found to be associated with any increase in sentence length. 


\section{References}

Australian Broadcasting Commission, 2002 "A Black Day for Justice”, Four Corners, broadcast 18 March 2002, online at http://www.abc.net.au/4corners/archives/2002a Monday18March2002.htm accessed 22 February 2003.

Australian Bureau of Statistics (2003) Crime and Safety, Australia, June 2003, Cat No 4509.0, online at http://www.abs.gov.au/Ausstats/abs@.nsf/e8ae5488b598839cca25682000131612/ 669c5a997eaed891ca2568a900139405!OpenDocument accessed 16 October 2003.

Australian Institute of Criminology (2003) Australian Crime Facts and Figures 2003, Canberra: Australian Institute of Criminology.

Australian Labor Party (2004) Peter Beattie and Labor Policy 2004, online at http://www.teambeattie.com.au accessed 26 February 2004.

Blakey, D (2000) Under the Microscope: Thematic Inspection Report on Scientific and Technical Support, London: Her Majesty's Inspectorate of Constabulary, online at http://www.nifs.com.au/NIFS/NIFS frame.html?references.asp\&1 accessed 15 August 2002.

Briody, M (2002) "The Effects of DNA Evidence on Sexual Offences in Court", Current Issues in Criminal Justice, vol 14, no 2, Nov 2002, pp 159-181.

Briody, M (2004a) "The Effects of DNA Evidence on Homicide Cases in Court", Australian and New Zealand Journal of Criminology, vol 37, no 2, pp 231-252.

Briody, M (2004b) The Effects of DNA Evidence on the Criminal Justice Process, Brisbane: PhD thesis, School of Criminology and Criminal Justice, Griffith University.

Briody, M and Prenzler, T (2005) "DNA Databases and Property Crime: A False Promise?", Australian Journal of Forensic Sciences, vol 37, no 3, Dec 2005, (forthcoming).

Burrows, J. and Tarling, R. 2004 "Measuring the impact of forensic science in detecting burglary and autocrime offences", Science \& Justice, vol 44, no 4, pp 217-222.

Crime and Misconduct Commission, 2002 Forensics Under the Microscope: Challenges in Providing Forensic Science Services in Queensland. Brisbane: Crime and Misconduct Commission, online at http://www.cmc.qld.gov.au/PUBS.html accessed 30 October 2002. 
Criminal Justice Commission (2001) Criminal Justice System Monitor, Brisbane: Criminal Justice Commission, Volume 5, April 2001.

CrimTrac (2004) online at http://www.crimtrac.com.au/htm accessed 26 October 2004.

Doneman, P. (2001) 'FBI to analyse ponytails from killer's home”, The Courier Mail, March 21, 2001, p 1.

Gans, J (2002) "The Quiet Devolution: How the Model Criminal Code Officers' Committee Botched New South Wales's DNA Law", Current Issues in Criminal Justice, vol. 14, no. 2, pp 210-223.

Gans, J and Urbas G (2002) DNA identification in the criminal justice system. Canberra: Australian Institute of Criminology Trends \& Issues in Crime and Criminal Justice No. 226, online at http://www.aic.gov.au/publications/tandi/tandi226.html accessed 15 September 2003.

Gaule, M (1999) Identifying the Effects of Timeliness of DNA Crime Stain Analysis on Resultant Detections, Sussex (UK) Police/ Forensic Science Service.

Green, K (2000) The Police Powers and Responsibilities and Other Acts Amendment Bill 2000: A DNA Regime for Queensland, Brisbane: Queensland Parliamentary Library, Legislation Bulletin No. 7/00, online at www.parliament.qld.gov.au/Parlib/Publications_pdfs/books/lb0700cg.pdf accessed 4 September 2002.

Harries, R (1999) The Cost of Criminal Justice, London: Home Office Research, Development and Statistics Directorate.

Nearhos, M and Bowman, J (1999) CrimTrac National DNA Criminal Investigation System Business Case, Canberra: Attorney-General's Department, Law Enforcement Coordination Division.

Office of Economic and Statistical Research (2001) Queensland Crime Victimisation Survey 2000, Brisbane: Queensland Government, online at www.oesr.qld.gov.au accessed 18 May 2004.

Peterson, J Ryan, J Houlden, P Mihajlovic, S (1987) "The Uses and Effects of Forensic Science in the Adjudication of Felony Cases", Journal of Forensic Sciences, JFSCA, vol 32, no 6, Nov 1987, pp 1730-1753.

Poulos, T (1993) Logistic Regression: Application of Advanced Statistical Methods to Criminal Justice Issues, Richmond, VA: Criminal Justice Research Center, Department of Criminal Justice Services. 
Queensland Government, Government Statistician's Office (1999) Crime and Justice Statistics Queensland 1997, Brisbane: Government Statistician's Office.

Queensland Health Scientific Services (2003) Annual Report 2002-03, Brisbane: Goprint.

Queensland Police Service (2004) Annual Statistical Review 2003-2004, Brisbane: Goprint, online at http://www.police.qld.gov.au/pr/services/statsnet/0304/pdf/crime200.pdf accessed 18 August 2005.

Queensland State Budget 2003-04 (2003) Department of Police: Ministerial Portfolio Statement, online at http://www.police.qld.gov.au/pr/services/budget/m_state2003.shtml accessed 23 September 2003.

Raymond J, Walsh S, Van Oorschot R, Gunn P and Roux C (2004) "Trace DNA: An Underutilized Resource or Pandora's Box? A Review of the use of Trace DNA Analysis in the Investigation of Volume Crime", Journal of Forensic Identification, 54:6.

Salmelainen, P (1995) The correlates of offending frequency: A study of juvenile theft offenders in detention, NSW Bureau of Crime Statistics and Research, Sydney: NSW Department of Attorney General.

Sears, A Neal, D and Robinson, S (2002) The Detection and Analysis of Trace DNA in Motor Vehicles, paper presented to the $16^{\text {th }}$ International Symposium of the Australian and New Zealand Forensic Science Society, Canberra, 12-17 May 2002.

Smith, A (2003) Personal communication from Dr Alaster Smith, Manager, Policing and Crime Reducing Unit, Home Office, UK, 14 February 2003.

Tabachnick, B and Fidell, L (2001) Using Multivariate Statistics, Needham Heights MA: Allyn and Bacon.

Tracy, P and Morgan, V 2000 "Big Brother and his science kit: DNA databases for $21^{\text {st }}$ century crime control?", The Journal of Criminal Law and Criminology, vol 90, no 2, pp 635-690.

van Kesteren, J Mayhew, P and Nieuwbeerta, P (2000) Criminal Victimisation in Seventeen Industrialised Countries: Key-findings from the international 2000 Crime Victims Survey, The Hague: Ministry of Justice, WODC. Onderzoek en beleid nr 187, online at http://www.unicri.it/icvs/publications/index pub.htm accessed 14 November 2004. 
Vanstone, A (1998) CrimTrac...using the latest in technology to fight crime. An Information Paper, Canberra: Minister for Justice, 16 September 1998.

Victorian Parliament Law Reform Committee (2004) Forensic Sampling and DNA Databases in Criminal Investigations, Melbourne: Government Printer, online http://www.parliament.vic.gov.au/lawreform/Forensic\%20Sampling\%20\&\%20D NA/FINAL\%20DNA\%20REPORT.pdf accessed 29 June 2004.

Walsh, S Moss, D Kliem, C and Vintiner, G (2002) "The collation of forensic DNA case data into a multi-dimensional intelligence database", Science \& Justice, vol 42, no 4, pp 205-214.

Ward, R (2004) Personal communication 23 ${ }^{\text {rd }}$ March 2004, Mr Raymond Ward, Acting Registrar (Administration), Brisbane Magistrates Court.

White, R and Perrone, S (1997) Crime and Social Control, Melbourne: Oxford University Press.

Wilson-Wilde, L (2001) "DNA Profiling and its Impact on Policing” in Use of DNA in the Criminal Justice System, Sydney: Institute of Criminology, Sydney University Law School, Papers from a Public Seminar, 11 April 2001, pp 2-6.

\section{Case Citations}

R. v. Frank Alan Button [2001] QCA 133.

\section{Legislation}

Juvenile Justice Act 1992 (Qld)

Police Powers and Responsibilities Act 2000 (Q1d.) 